\title{
Tonemic Substitution in Ekwulobia Igbo: A Descriptive Account
}

\author{
Chikelu Ihunanya Ezenwafor \\ DOI: http://dx.doi.org/10.4314/ujah.v14i1.8
}

\section{Abstract}

This paper presents an analysis of the tonal behavior of level tones in the Ekwulobia variety of Igbo. It gives a descriptive account of the peculiar tonal patterning of words in this lect. This unique tonal pattern is linked to insignificant and regular tonemic substitution realized especially on nouns and verbs in grammatical constructions. The choice of substitutable tonemes as observed from the analyzed data is highly Ezenwafordependent on the intuitive judgement of the native speaker. This work shows with adequate data, that regular tonemic changes are not always meaningful in Ekwulobia lect. Such tonemic alternations are therefore accorded phonetic status.

\section{Introduction}

Igbo like many other languages has many dialects. Oluikpe (1979) explains that the dialects of Igbo differ in a number of ways. These differences can be in form of variation in lexemes, pronunciation of words, tone etc. Ikekeonwu (1987) classifies Ekwulobia lect under the Aguata Inland West Igbo (Main dialect satellite). She equally observes that many dialects of the Aguata cluster exhibit a tonal patterning (especially in constructions) quite different from many other Igbo dialects. The foregoing lends support to the view of Pike (1948) who posits that "Over an extended geographical area, tonemes may be different in separate dialects of the same language. The number of tonemes may be the same but there 
may be a change in the systematic occurrence of these tonemes".

Ekwulobia lect is characterized by a rhythmic pattern that seems peculiar. The conspicuous nature of this unique phenomenon has motivated chants by Igbo speakers in mimicry of this variant. This paper gives a descriptive account of tonal alternation in Ekwulobia lect. It attributes the rhythmic tonal pattern of the dialect under study to what Pike (1948) calls tonemic substitution or tonal alternation. The rest of the paper goes into five different sections. Section 1.1 is on methodology. In section 2.0, we review relevant literature on tone and tonemic substitution. Section 3.0 covers data presentation and analysis and finally, 4.0, which states the implication of findings and conclusion.

\section{Methodology}

Oral interview/tape recording data collection technique was employed for the purpose of this research. Information was sought on general issues which motivated spontaneous response from interviewees. The informants selected are born and bred in Ekwulobia and are still residents there. They include two males and two females between the ages of 40-70.

\section{Tone}

Tone is a phonological category that distinguishes the meaning of words or utterances (Gussenoven 2004). It is a suprasegmental feature realized on syllables for the distinction of meaning. According to Pike (1948) "A tone language is one in which contrastive pitch levels do not merely form the intonation tune of a sentence but enters as a distinctive factor into the lexical elements of the language". In other words, tone distinguishes between the meanings of words with otherwise identical phonemic composition. In line with the above 
definitions, Igbo has been described as a register tone language with/comprising of three distinctive level tonemes. (high, low and step tone). The distinctive features of these level tonemes are evident in all dialects of Igbo and are also features of Ekwulobia tonemics.

Beside the lexical distinctiveness of level tonemes, they are also known to perform different functions in associative, specific and grammatical constructions. The inherent tone of lexical items in Igbo often changes when moved into constructive, specific and grammatical constructions. Williamson (1972) gives examples of significant tonal alternations in specific constructions. Be following examples are illustrative:
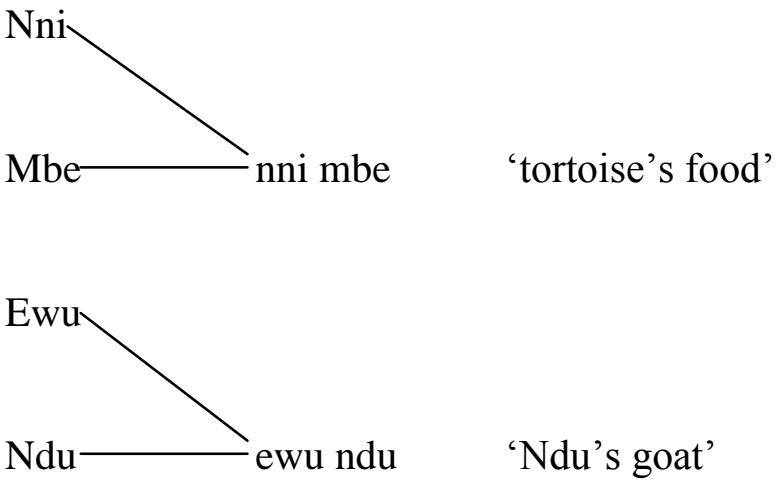

The low tone of the $\mathrm{N} 2$ in example 1 is replaced with a high tone to realize a 'possessive' meaning. The above phonemic feature of tone is prevalent in Igbo and its dialects. Our emphasis is however, not on the phonemic feature of tonal alternation but on the phonetic status.

This paper therefore, distinguishes between the phonemic and phonetic status of level tonemes in the Ekwulobia lect. Simply put, a level toneme assumes a phonemic status when its role is distinctive and a phonetic status when it plays a non-distinctive role. While a definite consensus has been reached concerning the distinctive feature 
and behavior of level tonemes in Igbo, the phonetic status of these tonemes seems to have received less attention.

\section{Tonemic Substitution (Tonal Alternation)}

It was stated earlier that the inherent tone of a word (in isolation) may differ from its tone when included in a phrase or sentence construction. Pike (1948) notes that "Under the circumstances appropriate to a given language, a syllable may have its normal tonemes removed and a different one substituted for it". Such regular tonemic substitutions in standard Igbo are mostly distinctive or significant. Thus, the meaning of a phrase or sentence may be modified on the basis of tonal alternation realized on the syllables of some words in the sentences. Added to the aforementioned significant tonemic substitution in the Ekwulobia lect is its peculiar nonsignificant or distinctive tonemic substitution. Pike (1948) first drew attention to such non-significant tonal alternation. According to him, "The rules for such changes are perfectly regular. This type of tonal interchange does not alter the meaning of the word or phrase but are mechanized rearrangements of tonemes."

He further termed these forced meaningless tonemic substitutions 'pertubations.' These non-significant alternations are predominant in Ekwulobia lect and contribute partially to its rhythmic speech pattern. In the subsequent section, we present and analyze language data reflecting non-significant but regular tonemic substitution in Ekwulobia variant of Igbo.

\section{Data Presentation and Analysis}

In this section, we focus on tonal alternation realized on two word groups (nouns and verbs). From the sample of available data, tonemic substitution seems restricted to the aforementioned word groups. In other words, other word 
groups like adverbs, adjectives, and conjunctions etc. hardly undergo such alternation. The lexical items and their tones are placed side by side their varied realizations in grammatical constructions.

\section{Tonemic Substitution on Verbs}

Verbs in Igbo have been classified according to their tone group (Nwachukwu, 1995). There are two major classes of simple verbs; the high tone verbs and the low tone verbs. On the basis of inflection, different verb forms are realized in Igbo. Our data include verbs in the past or stative forms (verb roots occurring with the Rv suffix) and the copular verb dụ (be). In the table below, the inherent tone of verbs is shown, as well as their different tonal realizations when used in grammatical constructions. Note that the tonal pattern of the verb forms in all 'A' examples correspond with what obtains in standard Igbo. For the high tone verb roots, the past and stative verb forms take the LL tones. In Ekwulobia variant, the usual LL tones can in addition, be substituted with the $\mathrm{HH}$ tones in certain grammatical constructions. 


\begin{tabular}{|c|c|c|}
\hline & Verbs & Verbs in Grammatical Constructions \\
\hline 1 & 'reach' lúrù -LL & $\begin{array}{l}\text { 1a) Ó lùrù áphíá 'He reached the market' } \\
\text { 1b) Áká yă lúrú 'His hands reached'. }\end{array}$ \\
\hline 2 & 'kill' & $\begin{array}{l}\text { 2a) Ágựụ gbùrù phé 'They were killed by hunger' } \\
\text { 2b)Ụphọ́dụ́ kà ágụụ gbúrú ‘Some were killed by hunger' }\end{array}$ \\
\hline 3 & ${ }^{\text {kwú }} \varlimsup_{\text {'talk' kwùrù- LL }}^{\text {kwúrú- HH }}$ & $\begin{array}{l}\text { 3a) Ó kwùrù ókwú 'He talked' } \\
\text { 3b) Kwá íphé ò kwúrú 'Hope that was what he said' }\end{array}$ \\
\hline 4 & gwwứíkē gựứ-HH 'Toụ̀rụi-LL & $\begin{array}{l}\text { 4a) Íké gwụ̀rụ yá 'He is tired' } \\
\text { 4b) Ónyé íké gwựựu 'Any one that gets tired' }\end{array}$ \\
\hline 5 & 'to be fat' vù̀rùrù- $\mathrm{LL}$ & $\begin{array}{l}\text { 5a) Jihī nè vùrù ívù 'This yam of yours is big/fat' } \\
\text { 5b)Kwàrà iphé jihī nè vúrú 'Look at how fat your yam is' }\end{array}$ \\
\hline 6 & $\begin{array}{l}\text { dà dàrà - LL } \\
\text { 'fall' dárá- HH }\end{array}$ & $\begin{array}{l}\text { 6a) Ọ́ dàrà n’àlà 'He fell on the ground' } \\
\text { 6b) Ọ́ wứrú ǹ̀ něrî dárá 'If its nightfall' }\end{array}$ \\
\hline 7 & $\int_{\text {'be' dụ }-H}^{\text {dụ }-L}$ & $\begin{array}{l}\text { 7a) Ọ́ dụ mmāā 'It is good' } \\
\text { 7b) Kèe kà ọ̀ dụ́? 'How is it?' }\end{array}$ \\
\hline
\end{tabular}

Table 1 
Observe from Table I the different tonemic realizations of the verbs. In example I, the verb 'luru' occurs with tow tone patterns; the LL and $\mathrm{HH}$ tones. In 1a, the tonal reading of 'luru' is realized as LL in the sentence medial positions. In $1 \mathrm{~b}$, the LL tones are substituted with the $\mathrm{HH}$ tones in sentence final position. This same alternation i.e., substitution of LL with $\mathrm{HH}$ tones applies to the other verb forms in examples 2-6. Example 7 involves the monosyllabic copula verb dụ (be) which bears a low tone in $7 \mathrm{a}$ and a high tone in $7 \mathrm{~b}$. The tonal alternation observed in the verb forms of (1b) to (7b) seems to be in total contrast with what is obtained in standard Igbo. As pointed out earlier, these verb forms which are realized tonally as $\mathrm{HH}$ in examples $1 \mathrm{~b}$ to $7 \mathrm{~b}$ maintain the LL tones in the ' $\mathrm{A}$ ' examples as is the case in standard Igbo. This regular change in the tonal pattern of verbs does not in any way, affect or modify the meaning of the grammatical constructions. Thus, such tonal alternations have been termed 'non-significant tonemic substitution'. The status of this level toneme interchange is therefore phonetic, that is, it is of no distinctive value. Observe also from the available data, that the substitution of LL tone verb forms by the $\mathrm{HH}$ tones is restricted to the sentence final positions as shown in examples $1 \mathrm{~b}$ to $7 \mathrm{~b}$.

\section{Tonemic Substitution on Nouns}

To characterize change in tonal pattern adequately, one must identify the inherent tone of the lexical item in question (Nwachukwu 1995). In line with this view, we list the nouns with their inherent tones and then, their different tonemic realizations extracted from the grammatical constructions used as examples. It is important to note that that the inherent tone of nouns presented below correspond strictly to what obtains in standard Igbo and also, the dialect under study. 


\begin{tabular}{|c|c|c|}
\hline & Nouns & Nouns in Grammatical Constructions \\
\hline 8. & local & $\begin{array}{l}\text { 8a) Ộkụkọ̣ Igbò jùrù bé yē 'His house is filled with local fowls' } \\
\text { 8b) Ó gòtèrè mmáyí Ígbō 'He bought local wine' }\end{array}$ \\
\hline 9. & 'honour' & $\begin{array}{l}\text { 9a) Ùgwù phiárá àhụu ńnwété 'Honour is hard to comeby' } \\
\text { 9b) Phá ñchā wụ̀ úgwū 'All are part of respect' }\end{array}$ \\
\hline 10. & 'Ùlà & $\begin{array}{l}\text { 10a) Ó bì n’Ựlà } \quad \text { 'He lives in Ụ̂là' } \\
\text { 10b) Ứmụnnà dụ̀ ụ̣bá n'Ựlá 'Kinsmen are many in Ùlà' }\end{array}$ \\
\hline 11. & únò $\varlimsup_{\text {ùnó }-\mathrm{LH}}$ & $\begin{array}{l}\text { 11a) Únò phé èvùká ‘Their house is big' } \\
\text { 11b) Ộ nọ̀ n'ùnó 'He is at home' }\end{array}$ \\
\hline 12. & 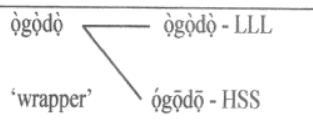 & $\begin{array}{l}\text { Ògọ̀dọ̀ yá ádọ́káná 'Her wrapper is torn' } \\
\text { Ímā òfú ọgọ̄dọ̄ 'To tie one wrapper' }\end{array}$ \\
\hline 13. & 'cọbàchà $\varlimsup_{\text {'cassava' ộbāchā- HSS }}^{\text {ò̀ - LLL }}$ & $\begin{array}{l}\text { 13a)Ộbàchà hirì ńnē 'Cassava is plenty' } \\
\text { 13b) Ó nwèrè mìbé ánáhā ákọ̀ ộāāchā 'There was a time } \\
\text { when cassava was not planted' }\end{array}$ \\
\hline 14. & $\begin{array}{l}\text { àchàlà } \\
\text { 'bamboo' }\end{array}$ & $\begin{array}{l}\text { 14a) Éji àchàlà àlụ únò 'Bamboo is used in building houses' } \\
\text { 14b) Ọ́ nà-àkụ ékwé áchālà' 'He is beating a bamboo gong' }\end{array}$ \\
\hline 15. & 'okro' & $\begin{array}{l}\text { 15a) Ọ́kwụ̀rụ dụ ụukọ́ 'There is scarcity of okro' } \\
\text { 15b) Ó gòtèrè ọ̀kwựự 'She bought okro' }\end{array}$ \\
\hline 16. & $\begin{array}{l}\text { Úgbògùrù } \\
\text { 'pumpkin' }\end{array}$ ùgbógúrú-LHHHrù-HLLL $^{\text {úgH }}$ & $\begin{array}{l}\text { 16a) Úgbògùnù ọ nà-ámì ányū? 'Does pumpkin yield anyu?' } \\
\text { 16b) Ọ́ kụ̆rù yá ùgbógúrú 'She planted pumpkin in it' }\end{array}$ \\
\hline
\end{tabular}

Table 2 
In Table 2, we focus on tonemic substitution on nouns. The disyllabic nouns with inherent LL tones as shown in examples 8,9 , and 10 have different tonemic realizations; the $\mathrm{LL}$ and $\mathrm{HH}$ tones respectively. In examples $8 \mathrm{a}, 9 \mathrm{a}$, and 10a, these nouns maintain their inherent tones. In $8 b$ and $9 b$ the LL tones on these nouns are alternated with $\mathrm{HS}$ tones and the $\mathrm{HH}$ tones in 10b. In example 11, the HL disyllabic noun 'uno' displays two tone patterns; the HL tones and the LH tones. The HL tones of $11 \mathrm{a}$ are substituted with $\mathrm{LH}$ tones in $11 \mathrm{~b}$. Examples 12, 13 and 14 involve trisyllabic nouns with inherent LLL tones. These inherent tones are maintained in examples 12a, 13a, and 14a. They are however, substituted with HSS tones in $12 \mathrm{~b}, 13 \mathrm{~b}$ and $14 \mathrm{~b}$. In example 15 , the trisyllabic noun 'okwụrụ' has two tone patterns; HLL and LLH tones. The inherent tone of the noun is maintained in 15a, but alternated with the $\mathrm{LHH}$ tones in $15 \mathrm{~b}$. For the polysyllabic noun 'ugboguru' exemplified in 16, two tone patterns are realized: the HLLL and the LHHH tones. The HLLL tones in 16a are substituted with the LHHH tones in $16 \mathrm{~b}$.

This consistent tonal alternation systematically occurs in the sentence final position i.e the tone of nouns in isolation is altered when such nouns occur in sentence final position but not in the initial or medial sentence positions. The affected nouns therefore possess the capacity for occurring with different tonemes in different grammatical constructions with no meaning alteration. The uniformity of these numerous substitutions cannot be coincidental. These non-significant tonemic substitutions form part of what gives the Ekwulobia lect its unique/rhythmic tonal patterning.

\section{Implication of Findings and Conclusion}

In Igbo language, it is often the case that the inherent tones of lexical elements change in particular constructions to add a new meaning or aid a grammatical function. Thus, we discuss tone in associative constructions, specific constructions etc. In 
such cases, tonemic alternation/substitution of lexical tones is assumed to be significant. While the above point holds for the Ekwulobia lect, this work has shown with adequate data that regular tonemic changes are not always meaningful. Therefore, meaningless change in the tonal pattern of words in grammatical constructions is accorded a phonetic status.

It is however, these mechanical non-significant tonemic substitutions (especially in sentence final positions) that motivate the unique and rhythmic tonal patterning of the Ekwulobia variant of Igbo.

Chikelu Ihunanya Ezenwafor is of the Department of Linguistics, Nnamdi Azikiwe University, Awka.

\section{Works Cited}

Gussenoven, C. The Phonology of Tone and Intonation. Cambridge University Press.2009.

Ikekeonwu,C. The Igbo Dialect Classification. A Seminar

Paper Presented in the Department of Linguistics, UNN. 1987, P 187.

Nwachukwu, PA. Tone in Igbo Syntax. Studies in Igbo Linguistics. Vol.2. 1995.

Nwaozuzu, G I. The Dialects of Igbo Language. University of Nigeria Press Ltd. 2008.

Oluikpe, B. Igbo Transformation Syntax. Onitsha: Africana Educational Publishers.1979.

Pike, K. Tone Languages. Ann Arbor: The University of Michigan Press.1948.

Williamson, K. The Igbo Associative and Specific Constructions. The Phonological Representation of Suprasegmentals. Eds. K. Bogers, H, Vander Hulst and M, Maarten. Dordretch, USA: Forris Publications. 1986: 195-208. 